УДК 027.7:025.4.03]:[001.811:177.9

DOI: 10.31866/2616-7654.5.2020.205729

\section{ФОРМУВАННЯ ІНФОРМАЦІЙНОЇ КОМПЕТЕНTHОСТI ЯК ЗАПОРУКА ДОТРИМАННЯ АКАДЕМІЧНОЇ ДОБРОЧЕСНОСТІ: РОЛЬ БІБЛІОТЕКИ ЗАКЛАДУ ВИЩОЇ ОСВІТИ}

Наталія Завадська,

заступник директора бібліотеки

Поліського національного університету, кандидат філологічних наук

(Житомир, Україна)

e-mail:zavadska1313@gmail.com

ORCID: https://orcid.org/0000-0002-0772-6942

Марина Ігнатюк,

директор бібліотеки

Поліського національного університету

(Житомир, Україна)

e-mail: marina.ignatyuk@gmail.com

ORCID: https://orcid.org/0000-0002-9872-0844

У статті аналізується взаємозалежність між формуванням інформаційної компетентності студентів та підвищенням рівня культури академічної доброчесності в освітньому середовищі. Актуалізовано важливість формування інформаційної компетентності студентів не лише для навчання, а й професійного становлення, самовдосконалення та вирішення життєвих завдань в особистій сфері. Мінливість та динамічність світу інформаційних технологій, суворі вимоги ринку праці та очікування роботодавців диктують потребу оволодіння майбутніми фахівцями універсальними знаннями, уміннями, навичками й особистими якостями, як-от, професійна мобільність, адаптивність, здатність оперативно здобувати нові знання, упевнена орієнтація у веб-середовищі та інформаційному просторі, що й передбачає комплексне формування інформаційної компетентності. Акцентовано наслідки недооцінювання формування інформаційної культури студентів на загальнонаціональному рівні (як для освіти й наукової комунікації зокрема, так і для успішного становлення інформаційного суспільства загалом). Підкреслено необхідність упровадження інформаційної культури інтегровано з основами академічного письма у навчальний процес як обов'язкової дисципліни. Проаналізовано фактори сприяння формуванню доброчесного освітнього середовища та укорінення у ньому базових цінностей академічної доброчесності. Обгрунтовано необхідність зміщення акцентів із боротьби із плагіатом у студентських роботах на розробку заходів щодо запобігання цьому явищу та підвищення інформаційної та академічної культури студентів. Розкрито роль та можливості бібліотеки ЗВО у створенні інформаційного простору, у якому дотримання норм академічної доброчесності є безперечною цінністю. Розглянуто новітні інтерактивні форми роботи бібліотеки та способи презентації освітнього контенту із урахуванням особливостей «кліпового мислення» сучасного покоління, як-от, ґейміфікація, імітаційні та інтерактивні ігри, веб-квести, відео-лекції тощо.

Ключові слова: інформаційна компетентність, інформаційна грамотність, інформаційне суспільство, бібліотека закладу вищої освіти, академічна доброчесність, академічна етика, плагіат, інтерактивні форми роботи. 
Український журнал з бібліотекознавства та інформаційних наук. Випуск 5 (2020) Ukrainian Journal on Library and Information Science. Issue 5 (2020)

\section{ВСТУП.}

У сучасному світі високих технологій, в еру становлення та розвитку інформаційного суспільства, навіть дитина у перші роки життя спроможна засвоїти алгоритм дій для користування сучасними гаджетами. Попри цей феномен, студенти закладів вищої освіти володіють досить обмеженим комплексом умінь та навичок орієнтування в розгалужених інформаційних потоках. Уміння критично осмислювати отриману інформацію, відмежовувати достовірні факти й наукові дані від необ'єктивних і псевдонаукових; структурувати отриману інформацію, виокремлюючи головне; формулювати релевантний пошуковий запит - ось комплекс компетентностей, який потрібен абітурієнтам ще до вступу у заклад вищої освіти, у якому згодом вони лише удосконалюватимуть свої здібності та здобуватимуть нові знання. Однак у процесі навчання виявляється, що у студентів постійно виникають труднощі з опрацюванням інформації для вирішення поставлених навчальних завдань. Найбільш проблемним є етап перетворення інформації, що передбачає критичне осмислення даних та їх порівняння, а також творчий етап, що вимагає створення власного інтелектуального продукту.

Недостатній рівень інформаційної культури та базових вмінь і навичок коректної роботи з інформацією часто призводить до порушення студентами норм академічної доброчесності, що набуває ознак системності та масштабності і становить загрозу формування суспільства, лояльного до вчинення плагіату. Фатальність наслідку недооцінювання важливості інформаційної культури та грамотності у тому, що у результаті доводиться спрямовувати усі зусилля на боротьбу iз плагіатом у студентських роботах, замість того, щоб навчати студентів дотримуватися академічної доброчесності та уникати плагіату. Це проблема національного масштабу, яка потребує негайного вирішення. Створення середовища, сприятливого для дотримання академічної доброчесності та нетерпимого до проявів плагіату, у загальнонаціональному контексті - завдання усіх наукових та освітніх закладів країни.

Мета пропонованої статті полягає в актуалізації важливості формування інформаційної компетентності студентів як цілісної системи, окресленні її діалектичного зв’язку із дотриманням академічної доброчесності, розкритті ролі та можливостей бібліотеки закладу вищої освіти (далі - 3ВО) у формуванні інформаційної компетентності користувачів та створенні середовища, сприятливого для утвердження фундаментальних цінностей академічної доброчесності. Основу методології дослідження становлять оглядово-аналітичний, системний, критичний та конструктивний методи.

Аналіз опублікованих упродовж останніх років праць, присвячених дослідженню інформаційної компетентності, свідчить про зацікавленість науковців насамперед питаннями розвитку та підвищення рівня інформаційної компетентності викладачів, а також залежності якості освітнього процесу від рівня сформованості цієї компетентності. Зокрема, у численних публікаціях розглянуто такі аспекти: важливість інформаційної компетентності як основи процесу інформатизації освіти та структурного компонента формування професійно-педагогічної складової педагога (Цьома, 2019), інформаційно-комунікаційна компетентність викладача ЗВО в організації сучасного навчального процесу в умовах його цифровізації (Дибкова, 2019), актуалізація необхідності підвищення інформацій- 
Бібліотечна практика: інформаційні і соціокультурні аспекти Library practice: informational and socio-cultural aspects

но-комунікаційної компетентності науково-педагогічних працівників як однієї з ключових (Морзе \& Буйницька, 2017), інформаційно-комунікаційна компетентність як компонент професійної компетентності педагога в умовах інформатизації системи освіти (Кузьменко \& Подліняєва, 2017), особливості процесу формування інформаційної компетентності як складової педагогічного менеджменту (Козир, 2016), інформаційна компетентність викладача та її складові у контексті створення інформаційного простору для самостійної роботи студентів (Нєлєпова, 2016) та ін. Натомість аспектам формування інформаційної компетентності учнів та студентів як суб’єктів навчального процесу приділено значно менше уваги дослідників. Насамперед актуалізуються такі питання, як особливості розвитку інформаційно-комунікаційної компетентності учасників навчального процесу (Ovcharuk \& Soroko, 2016), оцінювання та моніторинг інформаційно-комунікаційної компетентності школярів у контексті аналізу зарубіжного досвіду (Сороко, 2015), проблеми формування інформаційної компетентності сучасного учня (Чернуха \& Козир, 2015), аналіз структурних компонентів інформаційної компетентності та визначення критеріїв рівня її сформованості (В. І. Клочко \& О. В. Клочко, 2018) та ін.

Останнім часом актуальною темою є дотримання академічної доброчесності та протидія академічному плагіату. У сфері дослідження цієї тематики наразі 3'ясовано проблеми та соціальні загрози, пов'язані з реалізацією принципів академічної доброчесності у вітчизняному освітньо-науковому середовищі, та розроблено пропозиції щодо боротьби з порушеннями академічної доброчесності (Колесніков, 2019), обгрунтовано необхідність формування доброчесних культурних практик та їх поширення задля підвищення ефективності наукової діяльності та протидії плагіату (Гранчак \& Сошинська, 2019), проаналізовано сутність академічної доброчесності як політико-правової та морально-етичної проблеми (Ожеван, 2018), наведено перелік ознак, притаманних академічній доброчесності, та з'ясовано особливості нормативного регулювання академічної чесності як однієї зі складових системи забезпечення якості освіти (Тицька, 2018) та ін. Проблемі укорінення принципів академічної доброчесності в науковому середовищі та актуалізації важливості наукової етики для успішної кар'єри науковця присвячена колективна монографія «Академічна доброчесність: проблеми дотримання та пріоритети поширення серед молодих вчених» (2017). Особливості формування академічної культури в українському освітньому просторі та аналіз можливостей протидії девіантній суспільній практиці вчинення плагіату стали предметом дослідження у виданні «Академічна чесність як основа сталого розвитку університету» (2016). Адаптований для молодшої та середньої школи «Довідник $з$ академічної доброчесності для школярів» (2016), у якому розтлумачено важливість академічної доброчесності, сутність поняття «плагіат» та правила оформлення робіт задля його уникнення. Потужну інформаційну підтримку розвитку доброчесного академічного середовища в Україні та укорінення у національний грунт фундаментальних принципів академічної доброчесності надає «Проєкт сприяння академічній доброчесності в Україні» (SAIUP), що передбачає активне залучення МОН України задля трансформації національної системи освіти. Метою проєкту $€$ створення нової академічної культури, засадничими елементами якої є довіра, чесність, прозорість, реальні навчання та наукова робота (SAIUP, n. d.). 
Про усвідомлення важливості долучення бібліотеки до формування академічної доброчесності у навчальному закладі свідчить розробка експертами Української бібліотечної асоціації програми підвищення кваліфікації бібліотекарів «Академічна доброчесність та бібліотеки» (2018).

У публікаціях, що стосуються ролі бібліотек навчальних закладів у формуванні інформаційної компетентності студентів, актуалізовано насамперед такі аспекти, як: практичний досвід формування інформаційної культури користувачів у бібліотеці закладу вищої освіти (Грипич \& Буравкова, 2019); трансформація бібліотечної діяльності відповідно до вимог сучасності в умовах формування інформаційного суспільства (Гранчак, 2019); використання інформаційно-комунікаційних технологій у бібліотечній діяльності (Медведєва, 2019); роль бібліотек у розвитку інформаційної та мережевої медіа культури (Kulyk, 2018); участь бібліотеки у формуванні інформаційного простору та в інформаційному забезпеченні освітнього й наукового процесів (Жуков та ін., 2017); взаємозв'язок інформаційної культури учасників інформаційно-освітнього процесу у середовищі закладу вищої освіти та бібліотеки зокрема (Іванійчук, 2016) та ін. Водночас роль бібліотеки у формуванні інформаційної компетентності зокрема та інформаційної культури загалом у контексті впровадження принципів академічної доброчесності та етики в освітньо-науковому середовищі навчального закладу висвітлена недостатньо, як і питання діалектичного взаємозв'язку між формуванням інформаційної компетентності та дотриманням академічної доброчесності учасниками освітнього процесу.

\section{ІНФОРМАЦЙНА КОМПЕТЕНТНІСТЬ У КОНТЕКСТІ КОМПЕТЕНТНІСНОЇ ПАРАДИГМИ ОСВІТИ.}

Одним із пріоритетів сучасної системи освіти є реалізація компетентнісного підходу до навчання. Запровадження компетентнісного підходу сприяє підвищенню якості освіти та її модернізації, забезпеченню відповідності професійних та особистих якостей майбутніх фахівців очікуванням роботодавців, подоланню відірваності навчання від життя, забезпеченню зорієнтованості на ефективне застосування компетентностей у професійній діяльності, подальшому навчанні й самоосвіті, вирішенні життєвих завдань тощо. Ідея компетентнісного підходу $\epsilon$ ефективним способом вирішення протиріч у розвитку освіти та суспільства, у якому людина постає перед необхідністю повсякчас демонструвати свою компетентність у сфері професійної діяльності та набувати нових знань упродовж життя (Боднарук, 2017). Потенціал застосування компетентнісної парадигми в освіті передбачає формування професійно важливих якостей майбутніх фахівців, що є основою підвищення рівня соціальної успішності особистості, конкурентоспроможності на ринку праці, саморозвитку, самовираження й самореалізації та відповідальності за результати власної діяльності (Сидорчук, 2015, с. 26). Отже, основним результатом компетентнісного підходу має стати набуття суб’єктами освітнього процесу компетентностей, необхідних для життя, успішної соціалізації, ефективної професійної діяльності та самореалізації.

Поняття «компетентність» у системі вищої освіти визначається як здатність особи до навчання, провадження професійної діяльності й успішної соціалізації, що формується на базі динамічного поєднання знань, умінь і навичок, поглядів, 
Бібліотечна практика: інформаційні і соціокультурні аспекти Library practice: informational and socio-cultural aspects

цінностей, способів мислення тощо ("Про вищу освіту", 2014). Однією з ключових визначено компетентність, що пов'язана з розвитком інформаційного суспільства та інформаційно-комунікаційних технологій. Дефініція поняття «інформаційна компетентність» (часто означується як «інформаційно-комунікаційна компетентність») на рівні національного законодавства трактується з певними значеннєвими відтінками. Так, у Державному стандарті базової і повної загальної освіти (2011) використовується поняття «інформаційно-комунікаційна компетентність», яке трактується як використання інформаційно-комунікаційних технологій та відповідних засобів для виконання особистісних і суспільно важливих завдань. У тлумаченні поняття «інформаційна компетентність» у Державному стандарті початкової освіти (2018) основна увага зосереджена на акцентуванні цифрової грамотності для розвитку та спілкування, а також на кібербезпеці. Тоді як у Загальних критеріях оцінювання навчальних досягнень учнів у системі загальної середньої освіти (2008) у визначенні поняття «інформаційна компетентність» акцентована насамперед інформаційна складова: йдеться про вміння відбору, аналізу, оцінювання та систематизації інформації, використання джерел інформації та оволодіння новітніми інформаційними технологіями для особистого розвитку. Це поняття також використовується у значно ширшому трактуванні. У Концепції нової української школи (2016) інформаційна компетентність включає також цифрову складову і трактується як упевнене та водночас критичне використання інформаційно-комунікаційних технологій для роботи з інформацією (пошуком, обробкою, обміном) як на суспільному рівні, так і в особистому спілкуванні, а також включає інформаційну та медіа-грамотність, навички безпечної роботи з базами даних та ресурсами мережі інтернет, розуміння етики використання інформації, основи програмування тощо.

Серед науковців також немає одностайності у трактуванні такого багатоаспектного поняття, як інформаційна компетентність, яке до того ж часто ототожнюють із інформаційно-комунікаційною компетентністю. Проблема дефініції полягає у відсутності чіткого розмежування цих двох понять. Аналізуючи особливості інтерпретації науковцями поняття «інформаційно-комунікаційна компетентність», О. Овчарук та Н. Сороко відзначають варіативність конотацій цього поняття, яка зазвичай зводиться до надання дослідниками власних значеннєвих відтінків вже описаному та закріпленому у національних документах поняттю (Ovcharuk \& Soroko, 2016, с. 2). Зокрема, деякі дослідники розглядають інформаційну компетентність крізь призму використання інформаційно-комунікаційних технологій, інші - у контексті особливостей роботи з інформацією та використання інформаційно-пошукових систем (Когут, 2018, с. 252). Дискусійність підходів до визначення поняття «інформаційна компетентність» ускладнює його тлумачення, що залежить від контексту застосування терміна. Однак узагальнення усіх суперечностей щодо трактування інформаційно-комунікаційної компетентності свідчить про розуміння дослідниками цього поняття як доведеної здатності особистості працювати, відшуковуючи за допомогою різноманітних засобів через різні медіаресурси інформацію для комунікації, розв’язання проблем, здобуття нових знань та генерування рішень (Гуржій \& Овчарук, 2013, с. 42).

Отже, попри неоднозначність трактування науковцями багатоаспектного поняття «інформаційна компетентність», загалом дефініція цього терміна з тими чи 
іншими доповненнями базується на розумінні, що інформаційна компетентність $€$ насамперед комплексом знань, умінь, навичок, досвіду, ставлень, цінностей та особистих якостей, які спрямовані на ефективне та раціональне використання інформаційно-комунікаційних і комп'ютерних технологій, пошук, аналіз та критичне осмислення інформації, опанування раціональних прийомів роботи з різними видами та джерелами інформації для виконання різноманітних завдань в усіх сферах життя й упевненого орієнтування в інформаційному просторі.

Акцентуємо, що у визначенні напрямів формування інформаційної компетентності учасників освітнього процесу важливо концентруватися не лише на набутті відповідних знань, умінь та навичок, а й насамперед на розвитку інформаційної свідомості, відповідного способу мислення (критичність, логічність, аргументованість, перевірка фактів тощо), формуванні цілісної картини інформаційного світу, в якому студент вправно орієнтується, дотримується етичних принципів та 3 повагою ставиться до результатів чужої праці. У процесі формування інформаційної компетентності має відбуватися також інтеріоризація студентами цінностей та пріоритетів академічної доброчесності. Зокрема, Міжнародний центр академічної доброчесності виокремлює шість таких фундаментальних цінностей: чесність (honesty), довіру (trust), справедливість (fairness), повагу (respect), відповідальність (responsibility) та сміливість (courage), на базі яких формуються принципи доброчесної поведінки ("Fundamental Values of Academic Integrity", n. d.).

У сучасному динамічному та мінливому світі інформаційних технологій ринок праці диктує жорсткі вимоги до представників різних професій, які, окрім необхідних професійних компетенцій, повинні володіти універсальними вміннями та навичками: вмінням оперативно здобувати знання та адаптуватися до постійних змін і реформ, здатністю працювати в умовах постійного вдосконалення інформаційно-комунікаційних технологій, долати конфліктні ситуації, конструктивно сприймати виклики часу та відповідно реагувати на них (Гуржій \& Овчарук, 2013, с. 39). Здобуття цих універсальних знань, вмінь та особистісних якостей, необхідних для фахівців різних галузей професійної діяльності, передбачає формування інформаційної компетентності.

У Національній доктрині розвитку освіти (2002) та Законі України «Про вищу освіту» (2014) пріоритетним напрямом модернізації освіти визначено інформатизацію освітнього процесу та використання сучасних інформаційно-комунікаційних технологій для підготовки здобувачів освіти до життя та діяльності у динамічному світі інформаційного суспільства. Однак все ще залишається актуальною проблема розуміння важливості комплексного і системного, а не ситуативного формування інформаційної компетентності здобувачів вищої освіти. Одним із важливих кроків на шляху до забезпечення систематичного, цілеспрямованого формування інформаційної компетентності студентів вважаємо упровадження в освітній процес навчальної дисципліни «Інформаційна культура» як обов’язкової для усіх спеціальностей, починаючи з перших курсів навчання. Зазначимо, що протягом тривалого часу спостерігалося нівелювання важливості такого кроку на рівні діяльності одного з найвищих органів виконавчої влади. Ще у 2001 році Указом Президента України від 06.12.2001 р. №1193/2001 на Міністерство освіти і науки було покладено зобов’язання сформувати типові навчальні програми із дисципліни «Інформаційна 
культура» для середніх і вищих навчальних закладів ("Про рішення Ради", 2001). Однак зобов’язання так і не було виконано. Хоча іще у 1994-1995 роках відбувався активний процес підготовки Міністерством освіти і науки упровадження навчальної дисципліни «Основи інформаційної грамотності» у систему вищої освіти для різних спеціальностей бакалаврського рівня: спочатку як вибіркової дисципліни, а потенційно - 3 перспективою включення до переліку обов’язкових дисциплін, тоді ж було розроблено навчальну програму й навчальний посібник 3 цієї дисципліни, а також пакет програм «Інформаційна культура фахівця» (Шелестова, 2019). Десятки років заклади вищої освіти не надавали значення цій дисципліні. Наразі спостерігається активне впровадження курсів, присвячених формуванню у студентів інформаційної культури, назви яких варіюються: «Основи інформаційної культури», «Культура розумової праці», «Медійна та інформаційна грамотність» та ін. (Шелестова, 2019, с. 175). Однак не в усіх навчальних закладах запроваджується подібна ініціатива. До того ж така навчальна дисципліна не є обов'язковою, а часто пропонується як факультативна, вивчення якої зазвичай не передбачає жодної форми підсумкового контролю, наприклад, заліку. Це одразу демотивує студентів (знецінює отримання відповідних знань), сигналізуючи про відсутність необхідності відвідувати заняття з такої дисципліни. Адже наразі у вітчизняній системі освіти усе ще превалює «девіантна» мотивація студентів здобувати знання лише заради оцінок та отримання диплома.

3 іншого боку, доволі часто знецінення набуття інформаційних компетенцій студентами відбувається на рівні ставлення до інформаційної культури науково-педагогічних працівників навчальних закладів. В університетських спільнотах побутує думка, що здобуття необхідних знань та навичок щодо пошуку й осмисленого відбору наукової інформації та написання робіт відповідно до навчальних завдань відбувається автоматично у процесі вивчення студентами профільних дисциплін та завдяки роботі з навчальною літературою. Справді, відповідні компетенції мають формуватися у процесі вивчення кожної навчальної дисципліни, проте цьому аспекту потрібно свідомо приділяти увагу при розробці того чи іншого курсу. Важливо сформувати у студентів не поодинокі ситуативні вміння роботи з інформацією, а систематизований комплекс необхідних інформаційних знань, вмінь, навичок, цінностей та поглядів - інформаційну компетентність. Як показує практика, щоб опанувати, наприклад, навички академічного письма та роботи $з$ науковою інформацією задля кінцевого результату створення власного інтелектуального (творчого) продукту відповідно до вимог, використання як зразка наукової чи навчальної літератури є недостатнім. Першим серйозним викликом для здобувачів вищої освіти стає написання курсової роботи чи, тим паче наукової статті. Більшість студентів не в змозі впоратися навіть із написанням реферату. Очевидною є потреба у формуванні комплексу знань, умінь та навичок роботи з інформацією.

Важливо також розуміти, що освіта, головним завданням якої є винятково репродуктивність навчання - накопичення студентами знань зі спеціальності, $€$ абсолютно безперспективною. Адже особливістю інформаційного суспільства, в епоху становлення якого ми живемо, є перманентна мінливість, а отже, майбутній фахівець має бути підготовленим до ситуацій, у яких отримані ним знання можуть бути вже застарілими та неефективними. Тому першочергове завдання 
освіти - навчити вчитися, раціонально й ефективно працювати з інформацією та застосовувати набуті компетентності у житті для вирішення тих чи інших завдань. Як зазначає О. Скубашевська (2010), внаслідок якісних трансформацій інформаційного середовища відбуваються зміни у сфері освіти, зокрема, й у їі ключовій парадигмі: викладач перестав бути єдиним джерелом професійних знань для студента через доступність інших джерел інформації, а отже, змінилася й функція викладача, який насамперед повинен навчити студента правильному орієнтуванню в інформаційному просторі (с. 12). Важливо наголосити, що ефективність навчання та подальшого професійного становлення залежить від мотивації студентів, які повинні розуміти, для чого їм пропоновані компетенції, як і в яких ситуаціях їх можна застосувати та чи можна взагалі, чи знадобляться вони у житті. На ці питання студенти мають отримати чіткі відповіді. Такий підхід створює для студента цінність знань, отриманих при вивченні тієї чи іншої дисципліни.

Інформаційна компетентність є багатофункціональною і важливою не лише для успішного навчання студентів чи професійної діяльності майбутніх фахівців, а й для вирішення і розв’язання завдань та проблем у повсякденному житті, сфера якого повсякчас ігнорується. У формуванні інформаційної компетентності акцент має бути насамперед на розвитку здатності студентів практично використовувати набуті інформаційні компетенції, успішно застосовувати отриманий досвід, різноманітні прийоми та техніки в усіх сферах життя і діяльності. Зазначимо, що володіння інформаційною компетентністю передбачає не лише вміння користуватися комп’ютерною технікою та іншими технічними засобами. Це насамперед здатність впевнено почуватися у безмежному, динамічному, постійно змінному світі інформації та володіти такими якостями, як мобільність, універсальність, адаптивність, здатність швидко оновлювати власні знання й генерувати нові ідеї, конструктивно вирішувати конфлікти та продуктивно працювати в команді. Саме ці якості забезпечують конкурентоспроможність майбутнього фахівця на ринку праці, комфортне існування в інформаційному суспільстві, успішну самореалізацію та підвищення рівня життя як особистості зокрема, так і суспільства загалом. Інформаційна компетентність передбачає також вміння здобувати й опрацьовувати інформацію для безперервного самовдосконалення, саморозвитку, підвищення рівня професіоналізму, оволодіння новими потрібними знаннями, зокрема й навичками роботи 3 новітніми інформаційно-комунікаційними технологіями, які постійно оновлюються і модернізуються, та новими способами діяльності.

\section{ДОТРИМАННЯ АКАДЕМІЧНОЇ ДОБРОЧЕСНОСТІ: ВИКЛИКИ СЬОГОДЕННЯ.}

Від рівня інформаційної компетентності залежить рівень академічної культури студентства. Інформаційна компетентність зокрема й інформаційна культура загалом $є$ передумовою розвитку та водночас засобом формування етичної свідомості, відповідного способу мислення та моделі доброчесної поведінки учасників освітнього процесу, що передбачають сповідування принципів академічної доброчесності та ставлення з повагою до результатів чужої праці. В освітньому середовищі дотримання етичних норм у використанні інформаційних джерел та під час виконання письмових навчальних робіт наразі залишається гострою освітньою проблемою. 
Бібліотечна практика: інформаційні і соціокультурні аспекти

Library practice: informational and socio-cultural aspects

Варто зауважити, що нині потреба дотримання академічної доброчесності та популяризації фундаментальних цінностей цієї чесноти в освітньому та академічному середовищах чітко усвідомлена на державному рівні. В Україні активно проводиться робота з підтримки академічної доброчесності та протидії плагіату. Зокрема, Міністерство освіти та науки поширює серед освітніх закладів та наукових установ рекомендації щодо дотримання академічної доброчесності: Рекомендації щодо запобігання академічному плагіату та його виявлення у наукових роботах (2018) у листі МОН від 15.08.2018 р. № 1/11-8681, Методичні рекомендації для закладів вищої освіти з підтримки принципів академічної доброчесності у листі МОН від 23.10.2018 р. № 1/9-650 (2018), Рекомендації для закладів вищої освіти щодо розробки та впровадження університетської системи забезпечення академічної доброчесності (2019), затверджені рішенням Національного агентства із забезпечення якості вищої освіти від 29.10.2019 р. та ін.

У новому Законі України «Про повну загальну середню освіту» (2020), прийнятому 16 січня 2020 року, у розділі VI, де йдеться про забезпечення якості освіти, з'явився пункт про дотримання академічної доброчесності та види відповідальності за її порушення. Це важливе доповнення, що свідчить про обов’язкове дотримання кожним учасником освітнього процесу академічної доброчесності та проведення з цією метою відповідних заходів на усіх рівнях освіти. Зауважимо, що відповідно до Державного стандарту початкової освіти (2018) учень іще на першому рівні здобуття повної загальної середньої освіти повинен навчитися дотриманню етичних норм інформаційної взаємодії та правил безпечної й етичної діяльності в інформаційному суспільстві. Однак після здобуття повної загальної середньої освіти більшість випускників не володіють подібними компетенціями. Комбінація «сору-paste» в інформаційному світогляді потенційного студента стає універсальним, до того ж єдино можливим способом виконання навчального завдання чи написання будь-якої, навіть наукової, роботи. Така модель вирішення навчальних завдань переноситься і в середовище вищої освіти. Аналізуючи причини плагіату, О. Стрямець (2017) відзначає формування ще зі шкільної парти звички безпринципного використання чужих робіт з мережі інтернет задля отримання позитивної оцінки, така звичка разом із відсутністю покарання за подібні дії визначається автором як причини формування лояльної до плагіату ментальності українців (с. 67). За даними загальнонаціонального опитування студентів, проведеного у 2014-2015 роках у рамках проєкту «Академічна культура українського студентства: основні чинники формування та розвитку» (2015), до плагіату вдавалися 90 \% респондентів. Проведене на базі кількох університетів протягом 2015-2016 років опитування «Рецепція плагіату» виявило, що плагіат вчиняли 88 \% студентів (Рижко, 2016). Ці дані свідчать про масштабність і системність проблеми академічного шахрайства в освітньому середовищі та відсутність у студентів академічної культури. Тож потреба трансформації суспільної свідомості $є$ очевидною.

Акцентуємо, що вчинення плагіату може бути як свідомим актом, так і неусвідомленою дією через відсутність обізнаності з поняттям плагіату та сформованою звичкою використання компілятивного методу виконання навчальних завдань, який студент вважає загальноприйнятим та абсолютно легальним. Характерно, що доволі часто студенти, маючи лише загальне уявлення про плагіат, 
не розуміють особливостей поняття «академічний плагіат». Окрім того, вони не вміють належним чином оформлювати цитування та посилання або ж нехтують цими правилами, не усвідомлюючи важливості їх дотримання та загрози наслідків порушення академічної доброчесності. Подібні порушення демонструють численні звіти перевірки робіт студентів на наявність академічного плагіату за допомогою відповідних програм та сервісів. У контексті вирішення цієї проблеми важливу роль відіграє формування інформаційної компетентності та обізнаності студентів як чинника створення доброчесного освітнього середовища і дотримання принципів академічної доброчесності. Ефективним кроком у цьому напрямі вважаємо засвоєння студентами основ інформаційної культури у поєднанні $з$ навчанням основам академічного письма. Насамперед варто чітко донести до студентів інформацію про те, які дії можуть розцінюватися як плагіат, показати способи уникнення хибних кроків та створити позитивну мотивацію дотримання академічної доброчесності не лише у період навчання, а й у професійній діяльності у подальшому житті. Потрібно зруйнувати стереотипну думку студентів про те, що виконати навчальне завдання чи письмову роботу, не вдаючись до плагіату, неможливо. Окрім того, важливо створити необхідні умови для розкриття дослідницького потенціалу студентів, активізації пізнавального інтересу та мотивації до використання творчого підходу для вирішення навчальних завдань. Такий підхід сприятиме підвищенню якості освіти та рівня академічної культури.

За підтримки Проєкту сприяння академічній доброчесності в Україні (SAIUP) та Міністерства освіти і науки України Н. Шліхтою та I. Шліхтою було розроблено методичні рекомендації та базову програму курсу «Основи академічного письма», яку можна адаптувати відповідно до конкретних вимог університетів (Н. Шліхта \& I. Шліхта, 2016). Як зазначають автори, метою розробленого курсу $€$ подолання стереотипного сприйняття академічної доброчесності як абстракції та формування усвідомлення студентами практичної спрямованості поняття, а також розуміння, що отримані у процесі опанування основами академічного письма навички та вміння створення текстів та презентації власних думок як в усній, так і в письмовій формі є основою забезпечення успіху у будь-якій сфері (Н. Шліхта \& І. Шліхта, 2016, с. 6-7). У вище зазначеному формулюванні завдання курсу визначено в цілому важливість опанування студентами основ академічного письма, що, окрім формування навичок написання якісних наукових робіт, їх оформлення відповідно до вимог та дотримання академічної доброчесності, має універсальне практичне значення для студентів усіх спеціальностей як у сфері навчання, так і в майбутньому професійному та особистому житті. Адже написання та підготовка наукових робіт відповідно до вимог та правил виховує дисциплінованість, організованість, усвідомлення важливості дотримання дедлайну, допомагає формувати навички управління часом, розвивати критичне мислення, вміння аргументовано доводити свою позицію, переконувати, робити висновки, логічно, точно й чітко будувати висловлювання тощо (Н. Шліхта, 2020).

Отже, на нашу думку, підвищенню рівня академічної культури українського студентства та зміцненню академічної доброчесності в освітньому середовищі (викоріненню академічного шахрайства) сприяє здійснення відповідних заходів з урахуванням таких факторів: формування інформаційної компетентності зокрема та інформаційної культури загалом на кожному рівні освіти; забезпечення 
Бібліотечна практика: інформаційні і соціокультурні аспекти

Library practice: informational and socio-cultural aspects

позитивної мотивації до навчання (коли, наприклад, знання гарантують успішне працевлаштування майбутніх фахівців); створення загальнонаціонального тренду дотримання принципів академічної доброчесності та етики; систематична перевірка робіт на наявність академічного плагіату; обов’язковість покарань (дисциплінарні заходи) за порушення академічної доброчесності.

\section{РОЛЬ БІБЛІОТЕКИ У ФОРМУВАННІ ДОБРОЧЕСНОГО ОСВІТНЬОГО СЕРЕДОВИЩА ТА КОМФОРТНОГО ІНФОРМАЦЙНОГО ПРОСТОРУ.}

У Рекомендаціях для закладів вищої освіти щодо розробки та впровадження університетської системи забезпечення академічної доброчесності (2018) пропонуються такі інструменти впровадження академічної чесності в освітньо-наукову діяльність: інформаційно-консультативний супровід учасників освітнього процесу щодо питань дотримання академічної доброчесності (створення тематичних інформаційних ресурсів на власному сайті; розробка роздаткового інформаційного матеріалу, як-от, буклети, постери тощо); створення відеороликів, інфографіки; онлайн-курси, вебінари, семінари, лекції, тренінги за відповідною тематикою. Подібні заходи проводяться бібліотеками навчальних закладів, які зазвичай беруть безпосередню участь у створенні доброчесного освітнього середовища та популяризації принципів академічної чесності. Загалом бібліотека закладу вищої освіти має бути не лише підгрунтям освітньої діяльності та наукових досліджень, а й інформаційною базою забезпечення дотримання академічної доброчесності та етики в університетському середовищі.

Доволі часто у навчальних закладах саме бібліотеки здійснюють розробку та впровадження процедури перевірки робіт учасників освітнього процесу на наявність академічного плагіату за допомогою відповідного програмного забезпечення та координують цей процес. Таким чином бібліотека бере безпосередню участь у здійсненні функції контролю дотримання академічної доброчесності. Однак варто акцентувати, що проведення превентивних заходів із дотримання академічної доброчесності є значно ефективнішим, аніж боротьба із вірусним явищем плагіату. У цій сфері саме бібліотека може виявитися найбільш ефективним інструментом, що має потужний потенціал. Зауважимо, що на шляху підвищення рівня інформаційної та академічної культури студентів найбільшою складністю є втрата бібліотекою авторитету як джерела інформації та знань. Свідченням цієї проблеми є суттєве скорочення кількості користувачів, які для виконання навчальних завдань та письмових робіт користуються фондами бібліотеки чи її ресурсами. Однак у протистоянні з мережею інтернет бібліотека все ж має суттєву перевагу. Прихована загроза використання інтернет-джерел криється в тому, що на різноманітних базах рефератів і подібних сумнівних ресурсах, дуже популярних серед студентів, розміщені тексти без жодного посилання на автора. У споживача такої інформації поступово складається хибне враження відсутності власника тексту, що нібито дає право беззастережно його присвоїти, що й формує звичку вдаватися до плагіату. Окрім того, мережа інтернет - це нескінченний потік інформації, яка не завжди є достовірною, актуальною чи науковою. Не володіючи необхідними інформаційними компетенціями, дуже легко заблукати в інформаційних лабіринтах та втрапити на хибний шлях, що часто і трапляється зі студентами та молодими науковцями. Перевага бібліотеки у протистоянні 3 ме- 
режею інтернет у тому, що вона може навчити користувачів ефективно та раціонально працювати з інформацією. У цій площині бібліотека має створити цінність інших знань - стати дороговказом, орієнтиром, що скеровує на правильний шлях до самостійного отримання справді вартісних результатів, показує алгоритми та методи пошуку інформації, іiї критичного осмислення, аналізу, структурування та систематизації, а також можливості створення нових ідей на основі переосмисленої інформації. Бібліотека повинна створити імідж авторитетного структурного підрозділу навчального закладу, якому довіряють, до якого звертаються за допомогою та професійною консультацією. До того ж світ невпинно трансформується, оновлюються технології, стандарти та засоби праці, змінюються й інформаційні потреби та очікування користувачів, тому бібліотека має бути мобільною, швидко адаптуватися та оперативно реагувати на зміни і виклики сучасного світу.

У формуванні інформаційної компетентності студентів, яка має тісний зв’язок із компетенціями, що стосуються академічної доброчесності, ключові завдання діяльності бібліотеки вбачаємо у сприянні формуванню та удосконаленню здатності студентів ефективно здійснювати пошук інформації з використанням різних інформаційних джерел та баз даних; критично осмислювати інформацію, оцінювати її достовірність, актуальність та релевантність, систематизувати інформацію та створювати на їі основі нові ідеї та знання; вміння оформлювати запозичені з інших джерел думки, ідеї, відомості відповідно до вимог оформлення цитування та посилань; вміння користуватися засобами інформаційно-комунікаційних технологій та орієнтуватися у веб-середовищі. Насамперед потрібно зосередитися на створенні бібліотекою передумов для усвідомлення студентами життєвої необхідності самоосвіти упродовж всього життя та практичної цінності отриманих знань, умінь та навичок як для навчання, так і для вирішення завдань у професійній діяльності й особистому житті. Наразі актуальним завданням бібліотек $є$ перетворення власного інформаційного потенціалу на знаннєвий ресурс користувачів в умовах переорієнтації бібліотечного обслуговування з діалогічної моделі комунікації на полілогічну, у якій бібліотекар виступає як модератор комунікаційного процесу (Гранчак, 2019, с. 25).

Для активізації пізнавального інтересу студентів та мотивації до творчого і нестандартного вирішення завдань необхідно застосовувати цікаві, новітні, інтерактивні форми роботи. Абсолютно очевидно, що сухий виклад теорії, наприклад, з основ академічного письма, є абсолютно неефективним для засвоєння знань та формування позитивної мотивації до навчання й самоосвіти. Альтернативою таким громіздким лекціям може стати, наприклад, комплекс коротких, але змістовних відео-уроків із використанням інфографіки, що відображає основні поняття та положення відповідної теми. Акцентуємо, що у плануванні та розробці форм діяльності та заходів із формування інформаційної та академічної культури важливо враховувати особливості сприйняття студентів - сучасного покоління, яке виросло у цифровому світі. Йдеться про так зване «кліпове мислення», короткотривалість концентрації уваги та орієнтацію на візуальну презентацію освітнього контенту. Ефективним для навчання є застосування сучасних інформаційно-комунікаційних технологій, зокрема й мобільних додатків освітнього спрямування, що є перспективними та зручними технологіями не лише для використання під час аудиторних занять, а й для здобуття нових знань у процесі 
Бібліотечна практика: інформаційні і соціокультурні аспекти Library practice: informational and socio-cultural aspects

самоосвіти та самовдосконалення у найрізноманітніших сферах діяльності особистості (Бондаренко, 2018).

Ефективним засобом формування інформаційної компетентності студентів та навичок дотримання академічної доброчесності є використання різноманітних ігрових технологій, зокрема й комп’ютерних та онлайн-ігор. Подібний засіб навчання є досить популярним у діяльності бібліотек за кордоном. Зокрема, особливості «гейміфікації» діяльності бібліотеки як ефективного інструменту формування компетенцій з інформаційної грамотності та дотримання академічної доброчесності в системі вищої освіти висвітлено у публікації «Бібліотека у грі: навчання інформаційної грамотності та запобіганню плагіату» (Горбань \& Скаченко, 2019). Серед інших інтерактивних форм роботи бібліотеки виокремимо мультимедійні презентації з обов'язковим обговоренням матеріалу, бібліотечні ігри практичного спрямування (застосування на практиці в ігровій формі набутих компетенцій з інформаційної грамотності), веб-квести (наприклад, завуальований в ігровій формі пошук інформації у різноманітних базах даних), імітаційні ігри у рецензентів або експертів (наприклад, аналіз та робота над типовими помилками, допущеними у наукових роботах, аналіз звітів антиплагіатної перевірки робіт тощо), гра «бібліотечний консультант» (взаємне консультування студентів із питань, що стосуються інформаційної культури та академічної доброчесності, завдяки чому закріплюються знання та поглиблюється розуміння певної теми), бібліографічна мозаїка (укладання бібліографії відповідно до вимог у ігровій формі), бібліомікс (бібліографічний огляд необхідних для підготовки до написання роботи джерел, що включає документи різних видів: статті, дисертації, монографії, електронні джерела) тощо. Бібліотека також має здійснювати власне інформаційну функцію, систематично сповіщаючи учасників освітнього процесу про різноманітні інформаційні ресурси, бази даних як національного, так і міжнародного рівнів, тематичні вебінари та онлайн-курси, розроблені як бібліотекарями, так і авторитетними фахівцями з інших галузей.

Отже, якщо бібліотека у сучасному інформаційному світі з його потужними можливостями через об'єктивні обставини не може запропонувати цінності джерела знань, вона має створити іншу інформаційну цінність своїх послуг. У неосяжному глибоководному океані інформації бібліотека має запропонувати невмілому плавцеві рятівне коло, вказати орієнтири та навчити його плавати, до того ж зробити це творчо й нетривіально.

\section{ВИСНОВКИ.}

Взаємозумовленість розвитку інформаційної культури та культури академічної доброчесності дає змогу завдяки формуванню інформаційної компетентності студентів витворювати таку світоглядну картину інформаційного світу та комунікації учасників освітнього процесу, у якій навіть думка про вчинення плагіату $\epsilon$ неприпустимою, а чесність та відповідальність за результати власної діяльності стають основоположними принципами та моделлю поведінки у будь-яких ситуаціях. Тож зусилля усіх наукових та освітніх закладів і державних установ повинні бути спрямовані на створення загальнонаціонального тренду дотримання академічної доброчесності та поваги до результатів власної і чужої інтелектуальної і творчої діяльності. У цьому контексті варто акцентувати зміщення акцентів 
із боротьби з вірусним явищем плагіату, що набуває масштабу суспільної загрози, на дієвість запобігання його найменшим проявам завдяки підвищенню інформаційної грамотності студентів та обізнаності зі стратегіями уникнення плагіату й основними поняттями та принципами дотримання академічної доброчесності.

Наразі украй важливо привернути увагу до необхідності формування інформаційної компетентності студентів, як однієї із ключових компетентностей, важливих не лише для навчання та вивчення будь-яких дисциплін, а й для прийняття оптимальних рішень та успішного вирішення проблем як у професійній діяльності, так і в особистій сфері, врешті, для підвищення конкурентоспроможності майбутніх фахівців на ринку праці та успішної самореалізації у будь-яких сферах. Частково цю проблему можна вирішити шляхом уведення у навчальний процес як обов’язкової навчальної дисципліни «Інформаційна культура» (що включатиме також основи академічного письма), навчальний потенціал якої нині недооцінюється. Широкі можливості та перспективи у цьому напрямі діяльності відкриваються перед бібліотеками закладів вищої освіти. За допомогою використання сучасних інформаційних технологій та новітніх інтерактивних форм роботи з урахуванням особливостей мислення та сприйняття сучасного інформаційного покоління студентів бібліотека здатна не лише реалізовувати поставлені навчальні завдання, а й створювати умови для отримання студентами успішного досвіду практичного застосування набутих компетентностей, формувати позитивну мотивацію студентів до навчання, розвивати їхню здатність до творчого вирішення завдань і відкривати нові грані та можливості самоосвіти й самовдосконалення.

Перспективи подальших досліджень актуалізованого питання вбачаємо у розробці нових ефективних форм та методів роботи бібліотек закладів вищої освіти з використанням інформаційно-комунікаційних технологій для успішного та результативного формування інформаційної культури студентів та створення доброчесного освітнього середовища.

\section{СПИСОК ПОСИЛАНЬ}

Академічна доброчесність: проблеми дотримання та пріоритети поширення серед молодих вчених : колект. монографія / за заг. ред. Н. Г. Сорокіної, А. Є. Артюхова, І. О. Дегтярьової. Дніпро : ДРІДУ НАДУ, 2017. 169 с.

Академічна доброчесність та бібліотеки: програма підвищення кваліфікації працівників бібліотек / Укр. бібл. асоц., Голов. тренінг. центр для бібліотекарів ; розроб.: Воскобойнікова-Гузєва О. В., Загуменна В. В., Кулик Є. В., Пашкова В. С., Сербін О. О., Сошинська Я. Є., Шевченко І. О. Київ : УБА, 2018. 40 с.

Академічна культура українського студентства: основні чинники формування та розвитку : матеріали для ознайомлення з результатами проекту № 49169. 2015. URL: https:// cutt.ly/ByPl156 (дата звернення: 25.04.2020).

Академічна чесність як основа сталого розвитку університету / Міжнар. благод. фонд «Міжнар. фонд. дослідж. освіт. політики»; за заг. ред. Т. В. Фінікова, А. Є. Артюхова. Київ : Таксон, 2016. 234 с.

Боднарук I. Формування професійної компетентності майбутніх фахівців як педагогічна проблема сучасної вищої школи. Вісник Національної академії Державної прикордон- 
ної служби України. 2017. Вип. 3. URL: file://C:/Users/STESHE 1/AppData/Local/Temp/ Vnadped_2017_3_4.pdf (дата звернення: 25.04.2020).

Бондаренко В. Мобільні застосунки як інструмент самоосвіти в середовищі покоління Z. Український журнал з бібліотекознавства та інформаційних наук. 2018. № 1. С. 86-98.

Горбань Ю., Скаченко О. Бібліотека у грі: навчання інформаційної грамотності та запобіганню плагіату. Бібліотечний вісник. 2019. № 5. С. 26-33.

Гранчак Т. Орієнтири розвитку бібліотек у середовищі покоління Z. Український журнал з бібліотекознавства та інформаційних наук. 2019. Вип. 3. С. 20-35. URL: https://cutt. ly/LyP184K (дата звернення: 25.04.2020).

Гранчак Т., Сошинська Я. Академічний плагіат в Україні в умовах культурного транзиту. Міждисциплінарні дослідження складних систем. 2019. № 15. С. 107-127.

Грипич С., Буравкова Л. Формування інформаційної культури користувачів як важлива складова діяльності бібліотеки закладу вищої освіти. Бібліотечний форум: історія, теорія і практика. 2019. № 1. С. 33-40.

Гуржій А. М., Овчарук О. В. Дискусійні аспекти інформаційно-комунікаційної компетентності: міжнародні підходи та українські перспективи. Інформаційні технології в освіmi. 2013. Вип. 15. С. 38-43.

Державний стандарт базової і повної загальної середньої освіти : затв. постановою Кабінету Міністрів України від 23 листоп. 2011 р. № 1392. URL: https://cutt.ly/pyPl6qO (дата звернення: 25.04.2020).

Державний стандарт початкової освіти : затв. постановою Кабінету Міністрів України від 21 лют. 2018 р. № 87. URL: https://zakon.rada.gov.ua/laws/show/688-2019\%D0\%BF\#n8 (дата звернення: 25.04.2020).

Дибкова Л. М. Інформаційно-комунікаційна компетентність викладача закладу вищої освіти в умовах цифровізації освітнього процесу. Наукові записки Тернопільського національного педагогічного університету імені Володимира Гнатюка. Серія: педагогіка. 2019. № 1. С. 91-100.

Довідник з академічної доброчесності для школярів / уклад. М. В. Григор’єва, О. І. Крикова, С. Г. Пєвко ; за заг. ред. О. О. Гужви. Харків : ХНУ імені В. Н. Каразіна, 2016. 64 с.

Жуков І. А, Іванкевич О. В., Вахнован В. Ю. Шляхи створення єдиного інформаційного простору студентів та науковців за допомогою сучасних інформаційних технологій у Національному авіаційному університеті. Проблеми інформатизації та управління. 2017. T. $1 / 2$ (57/58). С. 31-37.

Загальні критерії оцінювання навчальних досягнень учнів у системі загальної середньої освіти : затв. наказом MOH України від 05 трав. 2008 р. № 371. URL: https://cutt.ly/ byPzwJJ (дата звернення: 25.04.2020).

Іванійчук Т. Ю. Інформаційна грамотність користувача бібліотечних послуг та компетентності бібліотечних працівників: взаємозв'язки та взаємовплив. Актуальні проблеми політики. 2016. Вип. 58. С. 227-240.

Клочко В. І., Клочко О. В. Дослідження структури складових інформаційної компетентності із застосуванням методу групування багатовимірних спостережень. Сучасні інформаційні технології та інноваційні методики навчання у підготовці фахівців: методологія, теорія, досвід, проблеми. 2018. Вип. 52. URL: https://cutt.ly/NyPzrjC (дата звернення: 25.04.2020).

Когут I. Інформаційна компетентність як структурний компонент професійно-педагогічної комунікативної компетентності педагога в сучасному освітньому просторі. Освітологічний дискурс. 2018. № 3/4. С. 246-258.

Козир М. В. Формування інформаційної компетентності викладача як складова педагогічного менеджменту. Освітологічний дискурс. 2016. № 2. C. 165-171. URL: https:/cutt. ly/yуРzуут (дата звернення: 25.04.2020). 
Колесніков А. Академічна доброчесність в українському освітньо-науковому просторі: проблеми та соціальні загрози. Регіональні аспекти розвитку продуктивних сил України. 2019. Вип. 24. С. 122-128.

Кузьменко В. В., Подліняєва О. О. Інформаційно-комунікаційна компетентність як складова загальної професійної компетентності педагога. Педагогічний альманах. 2017. Вип. 36. С. 110-116.

Медведєва В. Мультимедійні інформаційні технології в інформаційно-бібліотечному середовищі. Вісник Книжкової палати. 2019. № 2. С. 29-31.

Методичні рекомендації для закладів вищої освіти з підтримки принципів академічної доброчесності : лист МОН від 23.10.2018 р. № 1/9-650. 2018. URL: https://cutt.ly/ myPzfAF (дата звернення: 25.04.2020).

Морзе Н. В., Буйницька О. П. Підвищення рівня інформаційно-комунікаційної компетентності науково-педагогічних працівників - ключова вимога якості освітнього процесу. Інформаційні технології і засоби навчання. 2017. Т. 59, вип. 3. С. 189-200.

Національна доктрина розвитку освіти : затв. Указом Президента України від 12 квіт. 2002 p. № 347/2002. URL: https://cutt.ly/LyPzh8w (дата звернення: 25.04.2020).

Нєлєпова А. В. Інформаційна компетентність викладача в управлінні самостійною роботою студентів під час організації інформаційного середовища. Науковий часопис НПУ імені М. П. Драгоманова. Серія 5. Педагогічні науки: реалії та перспективи. 2016. Вип. 53. С. 201-213.

Нова українська школа: концептуальні засади реформування середньої школи. 2016. URL: https://cutt.ly/TyPzlgP (дата звернення: 25.04.2020).

Ожеван М. А. Академічна доброчесність як політико-правова та морально-етична проблема. Стратегічна панорама. 2018. № 2. С. 94-104.

Про вищу освіту : Закон України від 01 лип. 2014 р. № 1556-VII. Відомості Верховної Ради України. 2014. № 37/38. Ст. 2004. URL: https://zakon.rada.gov.ua/laws/show/1556-18 (дата звернення: 25.04.2020).

Про повну загальну середню освіту : Закон України від 16 січ. 2020 р. № 463-IX. URL: https:// cutt.ly/5yPzxVI (дата звернення: 25.04.2020).

Про рішення Ради національної безпеки і оборони України від 31 жовтня 2001 р. «Про заходи щодо вдосконалення державної інформаційної політики та забезпечення інформаційної безпеки України» : Указ Президента України від 6 груд. 2001 р. № 1193/2001. URL: https://cutt.ly/XyPzbEX (дата звернення: 25.04.2020).

Рекомендації для закладів вищої освіти щодо розробки та впровадження університетської системи забезпечення академічної доброчесності : затв. Рішенням Національного агентства із забезпечення якості вищої освіти від 29 жовт. 2019 р. Протокол № 11. URL: https://cutt.ly/myPzQzk (дата звернення: 25.04.2020).

Рекомендації щодо запобігання академічному плагіату та його виявлення у наукових роботах : лист MOH від 15.08.2018 р. № 1/11-8681. URL: https://cutt.ly/VyPzW08 (дата звернення: 25.04.2020).

Рижко О. М. Плагіат: складники розуміння. Держава та регіони. Серія: Соціальні комунікації. 2016. № 3. C. 40-48. URL: https://cutt.ly/MyPzR6U (дата звернення: 25.04.2020).

Сидорчук Н. Г. Компетентнісний підхід як ключова парадигма удосконалення підготовки професійних кадрів. Вісник Житомирського державного університету імені Івана Франка. 2015. Вип. 2. С. 26-30.

Скубашевська А. С. Філософія інноваційного розвитку освіти в умовах становлення інформаційного суспільства в Україні : автореф. дис. на здобуття наук. ступеня д-ра філос. наук : 09.00.10. Київ, 2010. 31 с.

Сороко Н. В. Оцінювання інформаційно-комунікаційної компетентності учнів загальноосвітніх навчальних закладів (досвід Латвії, Литви та Естонії). Наукові записки. Серія: 
Проблеми методики фізико-математичної і технологічної освіти. 2015. Вип. 7, ч. 3. С. $93-100$.

Стрямець О. Плагіат: проблеми виявлення та засоби попередження. Академічна доброчесність: проблеми дотримання та пріоритети поширення серед молодих вчених : колект. монографія / за заг. ред. Н. Г. Сорокіної, А. Є. Артюхова, І. О. Дегтярьової. Дніпро, 2017. С. 66-79.

Тицька Я. О. Академічна доброчесність як елемент системи забезпечення якості освіти. Науковий вісник Міжнародного гуманітарного університету. Серія: Юриспруденція. 2018. Вип. 34. С. 4-7.

Цьома Н. Інформаційна компетентність як один із компонентів формування професійно-педагогічної складової педагога. Педагогічні науки: теорія, історія, інноваційні технології. 2019. № 7. С. 317-324.

Чернуха Н. М., Козир М. В. Інформаційна компетентність - обов’язковий актив сучасного школяра. Педагогічна освіта: теорія і практика. Психологія. Педагогіка. 2015. № 23. C. 38-42.

Шелестова А. М. Інформаційна культура як навчальна дисципліна: історія становлення та сучасний стан. Вісник Харківської державної академії культури. 2019. Вип. 56. C. $167-182$.

Шліхта Н., Шліхта І. Основи академічного письма : метод. рек. та програма курсу. Київ, 2016. $61 \mathrm{c.}$

Шліхта Н. Мистецтво академічного письма: практичні поради : вебінар. URL: 3 https://cutt. ly/iyPzUjo (дата звернення: 25.04.2020).

Fundamental Values of Academic Integrity. International Centre for Academic Integrity : вебсайт. URL: https://cutt.ly/SyPzIcp (дата звернення: 25.04.2020).

Kulyk Ye. The Development of Network and Media Culture in Youth Library Facilities. Ukrainian Journal on Library and Information Science. 2018. № 1. C. 53-62 [in English].

Ovcharuk O., Soroko N. Information and Communication Competency Development in Education System: Modern Studies and Prospects. Інформаційні технології і засоби навчання. 2016. Т. 51, вип. 1. С. 1-7.

SAIUP: проект сприяння академічній доброчесності в Україні : веб-сайт. URL: https:/saiup. org.ua (дата звернення: 25.04.2020).

\section{REFERENCES}

Artiukhov, A., Bezus, R., Vasylieva, T., Dehtiarova, I., Yepifanova, Yu., Krashchenko, Yu., Kozyriev, V., Koldovskyi, A., Kurbatov, S. Serohina, T., Sorokina, N., Sidliarenko, A., Striamets, O., \& Tolstanova, H. (2017). Akademichna dobrochesnist: problemy dotrymannia ta priorytety poshyrennia sered molodykh vchenykh [Academic Integrity: Compliance Issues and Dissemination Priorities Among Young Scholars] [Monograph]. Dnipropetrovsk Rehional Institute for Public Administration, National Academy of Public Administration under the President of Ukraine [in Ukrainian].

Voskoboinikova-Huzieva, O. V., Zahumenna, V. V., Kulyk, Ye. V., Pashkova, V. S., Serbin, O. O., Soshynska, Ya. Ye., \& Shevchenko, I. O. (2018). Akademichna dobrochesnist ta biblioteky: prohrama pidvyshchennia kvalifikatsii pratsivnykiv bibliotek [Academic Integrity and Libraries: Librarians'Professional Development Program]. Ukrainian Library Association [in Ukrainian].

Akademichna kultura ukrainskoho studentstva: osnovni chynnyky formuvannia ta rozvytku : materialy dlia oznaiomlennia z rezultatamy proektu № 49169 [Academic Culture of Ukrainian Students: 
Main Factors of Formation and Development: Materials for Acquaintance with Project Results № 49169]. (2015). Retrieved April 25, 2020, from https://cutt.ly/ByPl156 [in Ukrainian].

Finikov, T. V., \& Artiukhov, A. Ye. (Eds.). (2016). Akademichna chesnist yak osnova staloho rozvytku universytetu [Academic Honesty as a Basis for Sustainable Development of the University]. Takson [in Ukrainian].

Bodnaruk, I. (2017). Formuvannia profesiinoi kompetentnosti maibutnikh fakhivtsiv yak pedahohichna problema suchasnoi vyshchoi shkoly [Formation of Professional Competence of Future Specialists as a Pedagogical Problem of Modern Higher Education]. Visnyk Natsionalnoi akademii Derzhavnoi prykordonnoi sluzhby Ukrainy, 3. file://C:/Users/ STESHE 1/AppData/Local/Temp/Vnadped_2017_3_4.pdf [in Ukrainian].

Bondarenko,V. (2018). Mobilni zastosunky yak instrument samoosvity v seredovyshchi pokolinnia Z [Mobile Applications as a Tool for Self-Education in Generation Z Environment]. Ukrainian Journal on Library and Information Science, 1, 86-98 [in Ukrainian].

Horban, Yu., \& Skachenko, O. (2019). Biblioteka u hri: navchannia informatsiinoi hramotnosti ta zapobihanniu plahiatu [Library in Game: Information Literacy Training and Plagiarism Prevention]. Bibliotechnyi visnyk, 5, 26-33 [in Ukrainian].

Hranchak, T. (2019). Oriyentyry rozvytku bibliotek u seredovyshchi pokolinnia Z [Landmarks for Developing Libraries in Generation Z Environment]. Ukrainian Journal on Library and Information Science, 3, 20-35. https://cutt.ly/LyPl84K [in Ukrainian].

Hranchak,T., \& Soshynska, Ya. (2019). Akademichnyi plahiat v Ukraini v umovakh kulturnoho tranzytu [Academic Plagiarism in Ukraine in the Conditions of Cultural Transit]. Interdisciplinary studies of complex system, 15, 107-127. https://doi.org/10.31392/ iscs.2019.15.107 [in Ukrainian].

Hrypych, S., \& Buravkova, L. (2019). Formuvannia informatsiinoi kultury korystuvachiv yak vazhlyva skladova diialnosti biblioteky zakladu vyshchoi osvity [Formation of Information Culture of Users as an Important Component of the Library of Higher Education Institution]. Bibliotechnyi forum: istoriia, teoriia i praktyka, 1, 33-40 [in Ukrainian].

Hurzhii, A. M., \& Ovcharuk, O. V. (2013). Dyskusiini aspekty informatsiino-komunikatsiinoi kompetentnosti: mizhnarodni pidkhody ta ukrainski perspektyvy [Discussion Aspects of Information and Communication Competence: International Approaches and Ukrainian Perspectives]. Informational technologies in education, 15, 38-43 [in Ukrainian].

Cabinet of Ministers of Ukraine. (2011). Derzhavnyi standart bazovoi i povnoi zahalnoi serednoi osvity [State Standard of Basic and Complete General Secondary Education]. Decree № 1392, 2011, November 23. https://zakon.rada.gov.ua/laws/show/1392-2011-\%D0\%BF [in Ukrainian].

Cabinet of Ministers of Ukraine. (2018). Derzhavnyi standart pochatkovoi osvity [State Standard of Primary Education]. Decree № 87, 2018, February 21. https://zakon.rada.gov.ua/laws/ show/688-2019-\%D0\%BF\#n8 [in Ukrainian].

Dybkova,L.M.(2019). Informatsiino-komunikatsiina kompetentnist vykladacha zakladu vyshchoi osvity v umovakh tsyfrovizatsii osvitnoho protsesu [Information and Communication Competence of a Teacher of Higher Education Institution in the Conditions of Digitalization of the Educational Process]. Scientific Issues of Ternopil Volodymyr Hnatiuk National Pedagogical University. Series: Pedagogy, 1, 91-100 [in Ukrainian].

Hryhor'ieva, M. V., Krykova, O. I., \& Pievko, S. H. (2016). Dovidnyk z akademichnoyi dobrochesnosti dlya shkolyariv [Handbook of Academic Integrity for Schoolchildren]. V. N. Karazin Kharkiv National University [in Ukrainian].

Zhukov, I. A, Ivankevych, O. V., \& Vakhnovan, V. Yu. (2017). Shliakhy stvorennia yedynoho informatsiinoho prostoru studentiv ta naukovtsiv za dopomohoiu suchasnykh informatsiinykh tekhnolohii u Natsionalnomu aviatsiinomu universyteti [Ways of Creation a Single Information Space for Students and Scientists Using Modern 
Information Technology at the National Aviation University]. Problems of Informatization and Management, 1/2(57/58), 31-37 [in Ukrainian].

Ministry of Education and Science of Ukraine. (2008). Zahalni kryterii otsiniuvannia navchalnykh dosiahnen uchniv u systemi zahalnoi serednoi osvity [General Criteria for Evaluating Students' Academic Achievement in General Secondary Education]. Decree № 371, 2008, May 5. https:// zakon.rada.gov.ua/rada/show/ru/v0371290-08 [in Ukrainian].

Ivaniichuk, T. Yu. (2016). Informatsiina hramotnist korystuvacha bibliotechnykh posluh ta kompetentnosti bibliotechnykh pratsivnykiv: vzaiemozv'iazky ta vzaiemovplyv [Information Literacy of Library Users and Competencies of Librarians: Relationships and Interactions]. Aktualni problemy polityky, 58, 227-240 [in Ukrainian].

Klochko, V. I., \& Klochko, O. V. (2018). Doslidzhennia struktury skladovykh informatsiinoi kompetentnosti iz zastosuvanniam metodu hrupuvannia bahatovymirnykh sposterezhen [Research of the Structure of Components of Information Competence Using the Method of Grouping Multidimensional Observations]. Suchasni informatsiini tekhnolohii ta innovatsiini metodyky navchannia u pidhotovtsi fakhivtsiv: metodolohiia, teoriia, dosvid, problemy, 52. https://cutt.ly/NyPzriC [in Ukrainian].

Kohut, I. (2018). Informatsiina kompetentnist yak strukturnyi komponent profesiinopedahohichnoi komunikatyvnoi kompetentnosti pedahoha v suchasnomu osvitnomu prostori [Information Competence as a Structural Component of a Teacher's ProfessionalPedagogical Communicative Competence in a Modern Educational Space]. Educological discourse, 3/4, 246-258 [in Ukrainian].

Kozyr, M. V. (2016). Formuvannia informatsiinoi kompetentnosti vykladacha yak skladova pedahohichnoho menedzhmentu [Formation of Information Competence of a Teacher as a Component of Pedagogical Management]. Educological discourse, 2, 165-171. https:// cutt.ly/yyPzyyT [in Ukrainian].

Kolesnikov, A. (2019). Akademichna dobrochesnist v ukrainskomu osvitno-naukovomu prostori: problemy ta sotsialni zahrozy [Academic Integrity in the Ukrainian Educational and Scientific Space: Problems and Social Threats]. Regional aspects of productive forces development of Ukraine, 24, 122-128 [in Ukrainian].

Kuzmenko, V. V., \& Podliniaieva, O. O. (2017). Informatsiino-komunikatsiina kompetentnist yak skladova zahalnoi profesiinoi kompetentnosti pedahoha [Information and Communication Competence as a Component of the General Professional Competence of a Teacher]. Pedahohichnyi almanakh, 36, 110-116 [in Ukrainian].

Medvedieva, V. (2019). Multymediini informatsiini tekhnolohii v informatsiino-bibliotechnomu seredovyshchi [Multimedia Information Technologies in the Information and Library Environment]. Bulletin of the Book Chamber, 2, 29-31 [in Ukrainian].

Ministry of Education and Science of Ukraine. (2018). Metodychni rekomendatsii dlia zakladiv vyshchoi osvity z pidtrymky pryntsypiv akademichnoi dobrochesnosti [Guidelines for Higher Education Institutions in Support of the Principles of Academic Integrity]. Letter № 1/9-650, 2018, November 23. https://cutt.ly/myPzfAF [in Ukrainian].

Morze, N. V., \& Buinytska, O. P. (2017). Pidvyshchennia rivnia informatsiino-komunikatsiinoi kompetentnosti naukovo-pedahohichnykh pratsivnykiv - kliuchova vymoha yakosti osvitnoho protsesu [Improving the Level of Information and Communication Competence of Research and Teaching Staff as a Key Requirement of the Guality of the Educational Process]. Information Technologies and Learning Tool, 59 (3), 189-200 [in Ukrainian].

Prezydent of Ukraine. (2002). Natsionalna doktryna rozvytku osvity [National Doctrine of Educational Development]. Decree № 347, 2002, April 12. https://zakon.rada.gov.ua/laws/ show/347/2002 [in Ukrainian].

Nieliepova, A. V. (2016). Informatsiina kompetentnist vykladacha v upravlinni samostiinoiu robotoiu studentiv pid chas orhanizatsii informatsiinoho seredovyshcha [Information Competence of a Teacher in the Management of Independent Work of Students During 
the Organization of the Information Environment]. Naukovyi chasopys NPU imeni M. P. Drahomanova. Seriia 5. Pedahohichni nauky: realii ta perspektyvy, 53, 201-213 [in Ukrainian].

Nova ukrainska shkola: kontseptualni zasady reformuvannia serednoi shkoly [New Ukrainian School: Conceptual Principles of Secondary School Reform]. (2016). https://cutt.ly/TyPzlgP [in Ukrainian].

Ozhevan, M. A. (2018). Akademichna dobrochesnist yak polityko-pravova ta moralno-etychna problema [Academic integrity as a political-legal and moral-ethical problem]. Strategic Panorama, 2, 94-104 [in Ukrainian].

Verkhovna Rada of Ukraine. (2014). Pro vyshchu osvitu [About Higher Education]. Law of Ukraine, № 1556-VII, 2014, Juli 1. Vidomosti Verkhovnoi Rady Ukrainy, 37/38, Art. 2004. https://cutt. ly/nyPzvxd [in Ukrainian].

Verkhovna Rada of Ukraine. (2020). Pro povnu zahalnu seredniu osvitu [About Complete General Secondary Education]. Law of Ukraine, № 463-IX, 2020, January 16. https://zakon.rada. gov.ua/laws/show/463-20 [in Ukrainian].

Prezydent of Ukraine. (2001). Pro rishennia Rady natsionalnoi bezpeky i oborony Ukrainy vid $31 z h o v t n i a 2001$ r. "Pro zakhody shchodo vdoskonalennia derzhavnoi informatsiinoi polityky ta zabezpechennia informatsiinoi bezpeky Ukrainy" [About the Decision of the National Security and Defense Council of Ukraine of 31 October. 2001 "About Measures to Improve the State Information Policy and Ensure Information Security of Ukraine"]. Decree № 1193, 2001, Dezember 6. https://cutt.ly/XyPzbEX [in Ukrainian].

Natsionalne ahentstvo iz zabezpechennia yakosti vyshchoi osvity. (2019). Rekomendatsii dlia zakladiv vyshchoi osvity shchodo rozrobky ta vprovadzhennia universytetskoi systemy zabezpechennia akademichnoi dobrochesnosti [Recommendations for Higher Education Institutions as for Development and Implementation of a University System of Academic Integrity]. Protocol № 11, 2019, October 29. https://cutt.ly/myPzQzk [in Ukrainian].

Ministry of Education and Science of Ukraine. (2018). Rekomendatsii shchodo zapobihannia akademichnomu plahiatu ta yoho vyiavlennia u naukovykh robotakh [Recommendations for the Prevention of Academic Plagiarism and Its Detection in Scientific Works]. Letter № 1/11-8681, 2018, August 15. https://cutt.ly/VyPzW08 [in Ukrainian].

Ryzhko, O. M. (2016). Plahiat: skladnyky rozuminnia [Plagiarism: Components of Understanding]. Derzhava ta rehiony. Seriia: Sotsialni komunikatsii, 3, 40-48. https://cutt.ly/MyPzR6U [in Ukrainian].

Sydorchuk, N. H. (2015). Kompetentnisnyi pidkhid yak kliuchova paradyhma udoskonalennia pidhotovky profesiinykh kadriv [Competency Approach as a Key Paradigm for Improving Professional Training of Personal]. Zhytomyr Ivan Franko State University Journal, 2, 26-30 [in Ukrainian].

Skubashevska, A. S. (2010). Filosofiia innovatsiinoho rozvytku osvity $v$ umovakh stanovlennia informatsiinoho suspilstva $v$ Ukraini [Philosophy of Innovative Development of Education in the Conditions of Formation of Information Society in Ukraine]. (Eztended abstract of Doctor's thesis). National Pedagogical Dragomanov University, Kyiv [in Ukrainian].

Soroko, N. V. (2015). Otsiniuvannia informatsiino-komunikatsiinoi kompetentnosti uchniv zahalnoosvitnikh navchalnykh zakladiv (dosvid Latvii, Lytvy ta Estonii) [Assessment of information and communication competence of students of secondary schools (experience of Latvia, Lithuania and Estonia)]. Naukovi zapysky. Seriia: Problemy metodyky fizyko-matematychnoi i tekhnolohichnoi osvity, 7(3), 93-100 [in Ukrainian].

Striamets, O. (2017). Plahiat: problemy vyiavlennia ta zasoby poperedzhennia [Plagiarism: Detection Problems and Prevention]. In N. H. Sorokina, A. Ye. Artiukhov, \& I. O. Dehtiarova (Eds.), Akademichna dobrochesnist: problemy dotrymannia ta priorytety poshyrennia sered molodykh vchenykh [Monohraph] (pp. 66-79). DRIDU NADU [in Ukrainian]. 
Tytska, Ya. O. (2018). Akademichna dobrochesnist yak element systemy zabezpechennia yakosti osvity [Academic Integrity as an Element of the Education Guality Assurance System]. Scientific Bulletin of the International Humanities University. Series: Jurisprudence, 34, 4-7 [in Ukrainian].

Tsoma, N. (2019). Informatsiina kompetentnist yak odyn iz komponentiv formuvannia profesiinopedahohichnoi skladovoi pedahoha [Information Competence as one of the Components of theFormingtheProfessionalandPedagogicalComponentofaTeacher].Pedagogicalsciences: theory, history, innovative technologies, 7, 317-324 [in Ukrainian].

Chernukha, N. M., \& Kozyr, M. V. (2015). Informatsiina kompetentnist - obov’iazkovyi aktyv suchasnoho shkoliara [Information Competence as a Compulsory Asset of the Modern Pupil]. Pedagogì̌na osvita: teorìa ì praktika. Psihologîâ, pedagogìka, 23, 38-42 [in Ukrainian].

Shelestova, A. M. (2019). Informatsiina kultura yak navchalna dystsyplina: istoriia stanovlennia ta suchasnyi stan [Information Culture as a Discipline: History of Formation and Current State]. Visnyk of Kharkiv State Academy of Culture, 56, 167-182 [in Ukrainian].

Shlikhta, N., \& Shlikhta, I. (2016). Osnovy akademichnoho pysma : metodychni rekomendatsii ta prohrama kursu [Basics of Academic Writing: Guidelines and Course Program]. Kyiv [in Ukrainian].

Shlikhta, N. (2020, April 4). Mystetstvo akademichnoho pysma: praktychni porady [The Art of Academic Writing: Practical Tips] : vebinar. [Video]. YouTube. https://www.youtube.com/ watch? $\mathrm{v}=$ TYtYgZDEVpE \&t=5436s [in Ukrainian].

Fundamental Values of Academic Integrity. (n. d.). International Centre for Academic Integrity. Retrieved April, 25, 2020, from https://cutt.ly/SyPzIcp [in English].

Kulyk, Ye. (2018). The Development of Network and Media Culture in Youth Library Facilities. Ukrainian Journal on Library and Information Science, 1, 53-62 [in English].

Ovcharuk, O., \& Soroko, N. (2016). Information and Communication Competency Development in Education System: Modern Studies and Prospects. Information Technologies and Learning Tools, 51(1), 1-7 [in English].

SAIUP: proekt spryiannia akademichnii dobrochesnosti v Ukraini [SAIUP: a Project to Promote Academic Integrity in Ukraine]. (n. d.). Retrieved April 25, 2020, from https://saiup.org.ua [in Ukrainian]. 
UDC 027.7:025.4.03]:[001.811:177.9

\author{
Nataliya Zavadska, \\ Deputy Director of the Library \\ of Polissia National University, \\ PhD in Philology (Zhytomyr, Ukraine) \\ e-mail: zavadska1313@gmail.com \\ ORCID: https://orcid.org/0000-0002-0772-6942 \\ Maryna Ignatiuk, \\ Director of the Library \\ of Polissia National University \\ (Zhytomyr, Ukraine) \\ e-mail: marina.ignatyuk@gmail.com \\ ORCID: https://orcid.org/0000-0002-9872-0844
}

\title{
FORMING OF INFORMATION COMPETENCE AS A PRECONDITION OF ACADEMIC INTEGRITY: THE ROLE OF THE LIBRARY OF HIGHER EDUCATION INSTITUTION
}

The article analyzes the interdependence between the formation of students' information competence and the enhancement of the culture of academic integrity in the educational environment. It is important to form students' information competence not only for education but also for professional formation, self-improvement and solving of life problems in the personal sphere has been actualized. The changeability and dynamism of the information technology world, the rigorous demands of the labor market and the expectations of employers dictate the need to master by future specialists with universal knowledge, skills, personal qualities, such as professional mobility, adaptability, ability to quickly acquire new knowledge, certain orientation in the web environment and information space, which implies complex formation of information competence. The consequences of underestimating the formation of students' information culture at the national level (for education and scientific communication in particular, and for the successful formation of the information society in general) are emphasized. The need to introduce an information culture integrated with the basics of academic writing into educational process as a compulsory discipline is underlined. The factors of promoting the formation of a moral educational environment and the rooting in it of the basic values of academic integrity are analyzed. The necessity of shifting the emphasis from the fight against plagiarism in student works to developing measures to prevent this phenomenon and enhance the information and academic culture of students is substantiated. The role and opportunities of the higher education institution's library in creating an information space in which adherence to standards of academic integrity is undeniable value are shown. The newest interactive forms of library work and ways of presenting educational content taking into account the features of "clip-thinking" of the modern generation, such as gamification, simulation and interactive games, web quests, video lectures and more are considered.

Keywords: information competence, information literacy, information society, library of higher education institution, academic integrity, academic ethics, plagiarism, interactive forms of work. 